\title{
ANALISIS RISIKO PADA USAHA PENANGKAPAN KEPITING BAKAU DI KECAMATAN SUNGAI KUNYIT KABUPATEN PONTIANAK
}

\author{
Imelda \\ Staf Pengajar Jurusan Sosial Ekonomi Pertanian \\ Fakultas Pertanian Universitas Tanjungpura
}

\begin{abstract}
Abstrak :
The aims of this research was : (1) to determine the level of income on crab fishing activities, (2) to determine the risk of cost, the risk of production, and the risk of income from crab fishing activities. Research area was determined by purposive in sub district Sungai Kunyit with the consideration that sub district of Sungai Kunyit as the center of fisheries sector in West Borneo Province and most of the people work as a fisherman. Analysis that implemented in this research was cost and income analysis and coefficient of variation analysis (CV).

The results show that the crab fishing activities in Mendalok village sub distric of Sungai Kunyit is profitable for the fisherman with level of income is Rp. 9.531.357,-/year. The risk of cost in crab fishing activities caused by the variance of fixed cost and variable cost. Ther risk of production in crab fishing activities caused by the variance of catch crabs, the limited of facilites and capital. The risk of income caused by the variance of catch crabs and the difference of selling price in the in the level of traders (retailers, traders and wholesalers.
\end{abstract}

Key words : analysis of risk, crab fishing activities, income. 


\section{PENDAHULUAN}

Sektor kelautan dan perikanan merupakan satu sektor andalan yang dituangkan dalam Rencana Pembangunan Jangka Menengah Daerah (RPJM-D) Provinsi Kalimantan Barat tahun 2008 hingga 2013. Sektor ini dipandang strategis karena berperan dalam menyediakan lapangan kerja dan peningkatan pendapatan masyarakat. Selain itu juga berperan sebagai bahan baku industri perikanan serta sebagai penyediaan makanan yang mengandung protein tinggi untuk meningkatkan kualitas Sumber Daya Manusia (SDM) masyarakat Kalimantan Barat.

Sektor perikanan tangkap di Provinsi Kalimantan Barat memberikan kontribusi terbesar bagi pembangunan sektor perikanan secara keseluruhan. Hal ini disebabkan karena potensi sumberdaya perikanan laut maupun perairan umum di Kalimantan Barat cukup besar, penduduk Kalimantan Barat sebagian besar tinggal di daerah pesisir sehingga pada umumnya mereka memilih profesi sebagai nelayan serta pengetahuan tentang pembudidayaan ikan yang dimiliki masyarakat pesisir yang pada umumnya masih sangat terbatas.

Melimpahnya sumberdaya laut dan semakin terbukanya akses pasar bagi komoditas hasil perikanan di Provinsi Kalimantan Barat telah memberikan peningkatan kesejahteraan bagi para nelayan terutama pemilik kapal. Salah satu potensi perikanan tangkap yang cukup menjanjikan dilihat dari permintaan dalam negeri dan permintaan luar negeri (ekspor) di Kalimantan Barat yaitu kepiting bakau. Berdasarkan data yang tersedia di Departemen Kelautan dan Perikanan, permintaan kepiting dan rajungan dari pengusaha restoran seafood Amerika Serikat saja mencapai 450 ton setiap bulan. Pürnal sosal Ekonoml Jumlah Nomor 1, April 2012. 


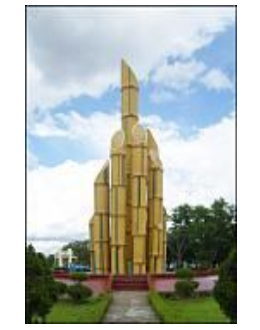

dipenuhi karena keterbatasan hasil tangkapan di alam dan produksi budidaya yang masih usaha penangkapan kepiting...

sangat minim. Padahal, negara yang menjadi tujuan ekspor kepiting bukan hanya Amerika tetapi juga Cina, Jepang, Hongkong, Korea Selatan, Taiwan, Malaysia, dan sejumlah negara di kawasan Eropa.

Kepiting banyak diminati karena daging kepiting yang lezat dan menyehatkan. Daging kepiting mengandung nutrisi penting bagi kehidupan dan kesehatan.

Meskipun mengandung kolesterol, makanan ini rendah kandungan lemak jenuh, merupakan sumber Niacin, Folate, dan Potassium yang baik, serta merupakan sumber protein, Vitamin B12, Phosphorous, Zinc, Copper, dan Selenium yang sangat baik.

Kepiting tersebut diekspor dalam bentuk segar/hidup, beku, maupun dalam kaleng. Di luar negeri, kepiting merupakan menu restoran yang cukup bergengsi.

Dan pada musim-musim tertentu, harga kepiting melonjak karena permintaan yang juga meningkat terutama pada perayaan-perayaan penting seperti hari raya, tahun baru, imlek dan lain-lain. Pada saat-saat tersebut harga kepiting hidup di tingkat pedagang pengumpul dapat mencapai Rp.100.000,- per kg, sedangkan pada hari biasa hanya Rp.40.000,- untuk grade CB (betina besar berisi/bertelur, ukuran > 200 g/ekor) dan Rp.30.000,- untuk LB (jantan besar berisi, ukuran > 500g$1000 \mathrm{~g} / \mathrm{ekor}$ ).

Kawasan pesisir di Desa Mendalok Kecamatan Sungai Kunyit Kabupaten Pontianak yang lokasinya berdekatan dengan beberapa pulau lainnya merupakan kawasan yang cocok untuk perkembangbiakan udang, kepiting serta berbagai jenis ikan dan biota laut lainnya. Sebagian besar masyarakat di Desa Mendalok bermukim di daerah pesisir dan bermata pencaharian sebagai nelayan. Beberapa alasan 
nelayan dalam melakukan penangkapan kepiting yaitu : 1) Wilayah penangkapan kepiting yang berada di sekitar pesisir memudahkan petani karena jarak tempuh yang tidak terlalu jauh sehingga dapat menghemat biaya produksi,

Kegiatan penangkapan kepiting dapat dilakukan setiap hari, bahkan pada saat terjadi musim selatan (bulan Oktober-Desember). Pada musim ini nelayan tidak bisa melaut di lepas pantai karena terjadi cuaca buruk yang disertai badai, sehingga banyak nelayan yang melakukan penangkapan kepiting.

Besarnya peluang nelayan dalam melakukan usaha penangkapan kepiting didukung oleh tingginya permintaan dan peluang pasar kepiting bakau. Pada pasar dalam negeri, kepiting bakau telah banyak dijual di pasaran-pasaran tradisional hingga ke swalayan mewah (supermarket), dan disajikan di rumah makan kecil di pinggiran jalan sampai restoran bahkan sampai hotel berbintang. Untuk pangsa pasar luar negeri (ekspor) kepiting bakau Indonesia yaitu negara Jepang, Malaysia, Prancis sampai ke Amerika Serikat (AS).

Pengembangan sektor perikanan, terutama perikanan tangkap adalah tidak mudah karena dihadapkan pada masalah risiko (risk) dan ketidakpastian (uncertainty). Dari segi produksi hasil tangkapan, risiko yang dihadapi oleh nelayan yaitu hasil tangkapan yang bervariasi karena nelayan di Desa Mendalok masih tergantung dengan alam dan cuaca atau musim. Hasil produksi perikanan tangkap (ikan dan kepiting) di Desa Mendalok Kecamatan Sungai Kunyit mengalami fluktuasi sesuai dengan musim penangkapannya, seperti terlihat pada tabel berikut. 


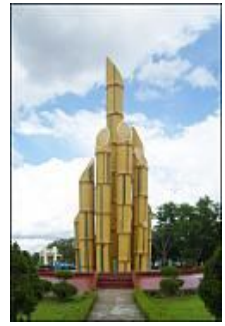

Imelda, analisis risiko pada usaha penangkapan kepiting..

Tabel 1.

Data Produksi Perikanan Tangkap di Desa Mendalok Kecamatan Sungai Kunyit

Tahun 2007

\begin{tabular}{|c|c|c|}
\hline Bulan & Ikan basah (kg) & Kepiting (kg) \\
\hline Januari & 460 & 200 \\
\hline Febuari & 870 & 350 \\
\hline Maret & 383 & 200 \\
\hline April & 450 & 240 \\
\hline Mei & 879 & 360 \\
\hline Juni & 1.458 & 350 \\
\hline Juli & 894 & 290 \\
\hline Agustus & 530 & 300 \\
\hline September & 250 & 480 \\
\hline Oktober & 458 & 990 \\
\hline Nopember & 870 & 870 \\
\hline Desember & 890 & 960 \\
\hline Total & 8.392 & 5.590 \\
\hline Sumber $:$ Kantor Kepala Desala &
\end{tabular}

Sumber : Kantor Kepala Desa Mendalok,2007

Risiko lain yang dihadapi oleh nelayan yaitu teknologi dalam penangkapan kepiting yang masih menggunakan cara tradisional sehingga mengakibatkan risiko yang cukup tinggi dalam pemasaran kepiting, misalnya banyak hasil tangkapan kepiting yang rusak (kehilangan capit, retak pada cangkang kepiting) bahkan terjadi risiko kematian pada kepiting karena tempat penyimpanan yang tidak memadai serta perlakuan pengemasan yang tidak sesuai untuk dipasarkan. Hal ini menyebabkan terjadinya penurunan berat atau bobot badan serta kualitas kepiting.

Berdasarkan latar belakang di atas, maka menarik untuk dikaji mengenai : 1) Berapa tingkat pendapatan yang diperoleh nelayan pada usaha penangkapan kepiting bakau di Kecamatan Sungai Kunyit Kabupaten Pontianak, dan 2) Bagaimana risiko produksi, risiko biaya dan dan risiko pendapatan pada usaha penangkapan kepiting 
bakau di Kecamatan Sungai

Kunyit Kabupaten Pontianak.

\section{METODE PENELITIAN}

Metode yang digunakan dalam penelitian ini adalah metode survey yaitu penyelidikan yang dilakukan untuk memperoleh fakta-fakta dan gejala-gejala yang ada secara faktual dari suatu kelompok atau suatu daerah tertentu (Nazir, 1988). Lokasi penelitian dipilih secara purposive di Desa Mendalok Kecamatan Sungai Kunyit Kabupaten Pontianak dengan pertimbangan bahwa daerah tersebut merupakan salah satu sentra penangkapan kepiting dan sebagian besar masyarakat bekerja sebagai nelayan. Populasi dalam penelitian ini yaitu nelayan yang ada di Desa Mendalok Kecamatan Sungai Kunyit berjumlah 70 orang. Pengambilan sampel menggunakan metode simple random sampling yaitu sebanyak 35 orang nelayan.
HASIL DAN PEMBAHASAN

Analisis Keuntungan Usaha Penangkapan Kepiting Bakau

1. Biaya Tetap

Biaya tetap pada usaha penangkapan kepiting bakau meliputi biaya penyusutan alat yaitu perahu, bubu, pancingan, jaring dan perangkap. Peralatan ini tidak habis dalam satu kali pemakaian sehingga dapat dipakai berulang kali untuk kegiatan penangkapan kepiting bakau. Biaya penyusutan alat terbesar yaitu pada perahu dan jaring karena harga beli yang relatif mahal sehingga nelayan juga perlu untuk melakukan perawatan kondisi perahu dan jaring supaya bisa dipakai lebih lama. Rekapitulasi biaya tetap pada usaha penangkapan kepiting bakau dapat dilihat pada Tabel 2 berikut. 


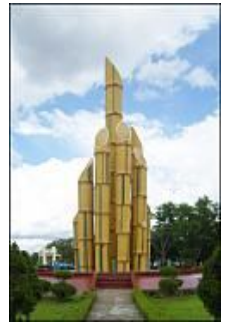

Imelda, analisis risiko pada usaha penangkapan kepiting...

Tabel 2.

Biaya Tetap Usaha Penangkapan Kepiting Bakau

\begin{tabular}{|c|l|r|}
\hline No. & \multicolumn{1}{|c|}{ Jenis Peralatan } & Biaya Penyusutan (Rp/tahun) \\
\hline 1. & Perahu & $117.142,86$ \\
\hline 2. & Bubu & $22.642,86$ \\
\hline 3. & Pancingan & $15.785,71$ \\
\hline 4. & Jaring & $110.000,00$ \\
\hline 5. & Perangkap & $17.643,00$ \\
\hline \multicolumn{2}{|r|}{ TOTAL BIAYA TETAP }
\end{tabular}

Sumber : Analisis Data Primer, 2011

2. Biaya Variabel

Biaya variabel pada usaha penangkapan kepiting bakau meliputi biaya keranjang dan biaya tenaga kerja. Besar kecilnya biaya variabel bervariasi tergantung pada musim penangkapan kepiting. Penggunaan biaya variabel dikelompokkan kedalam empat musim, yaitu Musim I (Timur) terjadi pada bulan Januari - Maret, musim II (Utara) terjadi pada bulan April - Juni, musim III (Barat) terjadi pada bulan Juli - September, dan musim IV (Selatan) terjadi pada bulan Oktober - Desember. Biaya variabel terbesar terjadi pada musim IV karena pada musim ini, banyak nelayan yang tidak melaut dan beralih melakukan penangkapan kepiting sehingga terjadi peningkatan biaya tenaga kerja dan biaya keranjang. Keranjang yang digunakan oleh nelayan ditujukan untuk mengumpulkan hasil tangkapan kepiting serta untuk memudahkan nelayan dalam proses penjualan dan pendistribusian ke pedagang. Rekapitulasi biaya variabel pada usaha penangkapan kepiting bakau dapat dilihat pada Tabel 3 berikut. 
Tabel 3.

Total Biaya Variabel pada Usaha Penangkapan Kepiting Bakau

\begin{tabular}{|c|c|c|c|c|c|c|}
\hline No & Jenis Biaya & $\begin{array}{r}\text { Musim } \\
\text { I }\end{array}$ & $\begin{array}{r}\text { Musim } \\
\text { II }\end{array}$ & $\begin{array}{r}\text { Musim } \\
\text { III }\end{array}$ & $\begin{array}{r}\text { Musim } \\
\text { IV }\end{array}$ & $\begin{array}{r}\text { Total Biaya } \\
\text { (Rp/tahun) }\end{array}$ \\
\hline 1. & Keranjang & $70.285,71$ & $31.142,86$ & $75.142,86$ & $136.142,86$ & 312.714 .29 \\
\hline 2. & $\begin{array}{l}\text { Tenaga } \\
\text { Kerja }\end{array}$ & $2.180 .000,00$ & $2.157 .142,86$ & $3.040 .000,00$ & $4.100 .000,00$ & $11.477 .142,86$ \\
\hline \multicolumn{5}{|c|}{ Total } & Biaya Variabel & $11.789 .857,15$ \\
\hline
\end{tabular}

Sumber : Analisis Data Primer, 2011

Berdasarkan tabel 2 dan 3 di atas, sebesar 97,65 \% dari total biaya dapat dianalisis rata-rata total usaha penangkapan kepiting biaya usaha penangkapan bakau. Hal ini menunjukkan kepiting bakau seperti pada tabel bahwa nelayan mengeluarkan 4 berikut. Persentase terbesar yaitu pada biaya variabel (biaya keranjang dan biaya tenaga kerja) alokasi modal terbesar pada biaya variabel khususnya biaya tenaga kerja.

Tabel 4.

Total Biaya pada Usaha Penangkapan Kepiting Bakau

\begin{tabular}{|c|l|r|r|}
\hline No. & Jenis Biaya & $\begin{array}{c}\text { Biaya Penyusutan } \\
\text { (Rp/tahun) }\end{array}$ & \multicolumn{1}{|c|}{ Persentase (\%) } \\
\hline 1. & Biaya Tetap & $283.214,43$ & $2,35 \%$ \\
\hline 2. & Biaya Variabel & $11.789 .857,15$ & $97,65 \%$ \\
\hline \multicolumn{2}{|c|}{ TOTAL BIAYA } & $12.073 .071,58$ & $100 \%$ \\
\hline
\end{tabular}
Sumber : Analisis Data Primer, 2011

3. Hasil Tangkapan Kepiting

Hasil tangkapan kepiting nelayan bervariasi tergantung musim tangkapan kepiting, dengan hasil tangkapan kepiting terbesar terjadi pada musim IV yaitu sebesar 566,40 kg. Jumlah hasil tangkapan kepiting yang dianalisis dalam penelitian ini yaitu hasil tangkapan yang dijual ke pedagang,

tidak

memasukkan hasil tangkapan yang merupakan konsumsi keluarga nelayan. Jumlah hasil tangkapan kepiting konsumsi keluarga nelayan berkisar antara 15-20 $\mathrm{kg} / \mathrm{musim}$ tangkapan dan seringkali diambil dari kepiting yang berukuran Pertanian, Volume 1 ,

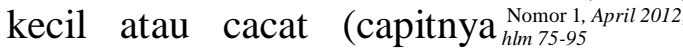
patah) sehingga tidak laku 


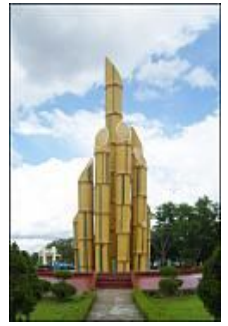

Imelda, analisis risiko pada usaha penangkapan kepiting.. terjual. Rekapitulasi hasil tangkapan kepiting bakau dapat dilihat pada Tabel 5 berikut.

Tabel 5.

Hasil Tangkapan pada Usaha Penangkapan Kepiting Bakau

\begin{tabular}{|c|l|r|}
\hline No. & \multicolumn{1}{|c|}{ Musim } & Hasil Tangkapan Kepiting (kg) \\
\hline 1. & Musim I & 135,03 \\
\hline 2. & Musim II & 138,00 \\
\hline 3. & Musim III & 308,14 \\
\hline 4. & Musim IV & 566,40 \\
\hline $\begin{array}{l}\text { Total Hasil Tangkapan Kepiting } \\
\text { (kg/tahun) }\end{array}$ & $1.147,57$ \\
\hline
\end{tabular}

Sumber : Analisis Data Primer, 2011

4. Penerimaan

Penerimaan yang diperoleh

nelayan pada usaha

penangkapan kepiting bakau

berfluktuasi sesuai hasil

tangkapan kepiting bakau.

Penerimaan tertinggi yang

diperoleh nelayan terjadi pada Musim IV (Musim

Selatan) dan penerimaan terendah terjadi pada Musim

I. Rekapitulasi penerimaan pada usaha penangkapan kepiting bakau dapat dilihat pada Tabel 6.

Tabel 6.

Penerimaan pada Usaha Penangkapan Kepiting Bakau

\begin{tabular}{|c|l|r|}
\hline No. & \multicolumn{1}{|c|}{ Musim } & Penerimaan (Rp) \\
\hline 1. & Musim I & $2,529,428.57$ \\
\hline 2. & Musim II & $2,595,714.29$ \\
\hline 3. & Musim III & $5,713,000.00$ \\
\hline 4. & Musim IV & $10,766,285.71$ \\
\hline \multicolumn{2}{|c|}{ Total Penerimaan (Rp/tahun) } & $21,604,428.57$ \\
\hline
\end{tabular}

Sumber : Analisis Data Primer, 2011

5. Keuntungan

Rata-rata keuntungan yang diperoleh nelayan pada usaha penangkapan kepiting bakau yaitu Rp. 9.531.357/tahun.
Analisis

Risiko

Usaha

Penangkapan Kepiting Bakau

Risiko pada usaha penangkapan kepiting bakau di Desa Mendalok Kecamatan Sungai Kunyit terdiri dari risiko 
biaya, risiko produksi dan risiko keuntungan. Ketiga jenis risiko ini dapat diketahui dengan analisis koefisien variasi (CV). Analisis koefisien variasi (CV) merupakan perbandingan antara nilai standar deviasi dengan nilai

\begin{abstract}
rata - rata atau nilai yang diharapkan sehingga dapat diketahui besarnya risiko relatif biaya, produksi dan keuntungan pada usaha penangkapan kepiting bakau (Pappas dan Hirschey, 1995).
\end{abstract}

Tabel 7.

Risiko Biaya, Risiko Produksi dan Risiko Keuntungan Pada Usaha Penangkapan Kepiting Bakau

\begin{tabular}{|c|c|c|c|c|c|}
\hline \multicolumn{2}{|c|}{ Risiko Biaya } & \multicolumn{2}{|c|}{ Risiko Produksi } & \multicolumn{2}{|c|}{ Risiko Keuntungan } \\
\hline Uraian & Nilai & Uraian & Nilai & Uraian & Nilai \\
\hline $\begin{array}{l}\text { Rata - rata } \\
\text { Biaya }\end{array}$ & $\begin{array}{c}12.073 .07 \\
1,43\end{array}$ & $\begin{array}{l}\text { Rata - rata } \\
\text { Produksi }\end{array}$ & $1.147,57$ & $\begin{array}{ll}\text { Rata } \quad- & \text { rata } \\
\text { Keuntungan } & \end{array}$ & $\begin{array}{c}9.531 .357, \\
14\end{array}$ \\
\hline $\begin{array}{l}\text { Standar } \\
\text { Deviasi }\end{array}$ & $\begin{array}{c}2.155 .447, \\
88\end{array}$ & $\begin{array}{l}\text { Standar } \\
\text { Deviasi }\end{array}$ & 127,92 & Standar Deviasi & $\begin{array}{c}\text { 6.962.601, } \\
42\end{array}$ \\
\hline $\begin{array}{l}\text { Koefisien } \\
\text { Variasi } \\
(\mathrm{CV})\end{array}$ & 0,178 & $\begin{array}{l}\text { Koefisien } \\
\text { Variasi (CV) }\end{array}$ & 0,111 & $\begin{array}{ll}\text { Koefisien } & \text { Variasi } \\
(\mathrm{CV}) & \end{array}$ & 0,73 \\
\hline $\mathrm{CV}(\%)$ & $17,8 \%$ & $\mathrm{CV}(\%)$ & $11.1 \%$ & $\mathrm{CV}(\%)$ & $73 \%$ \\
\hline
\end{tabular}

\section{Risiko Biaya}

Analisis risiko biaya

pada usaha penangkapan kepiting dilakukan dengan analisis koefisien variasi (CV) dengan menggunakan data biaya usahatani, seperti terlihat pada tabel 7 , dengan nilai koefisien variasi sebesar $17,8 \%$. Risiko biaya pada usaha penangkapan kepiting bakau disebabkan oleh adanya variasi pada biaya tetap dan variabel. Variasi terbesar terjadi pada biaya variabel (biaya keranjang dan biaya tenaga kerja), karena perbedaan musim pada kegiatan penangkapan kepiting. Gambaran rata-rata biaya variabel pada usaha penangkapan kepiting berdasarkan tangkapan di musim Mendalok Kecamatan ${ }^{\text {Nomor } 7 \text { - } 1,95}$ 


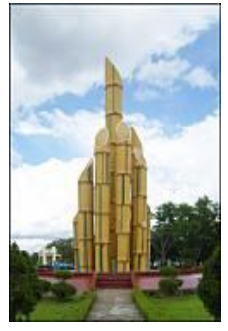

Imelda, analisis risiko pada usaha penangkapan kepiting...

Sungai Kunyit dapat dilihat pada gambar 1.

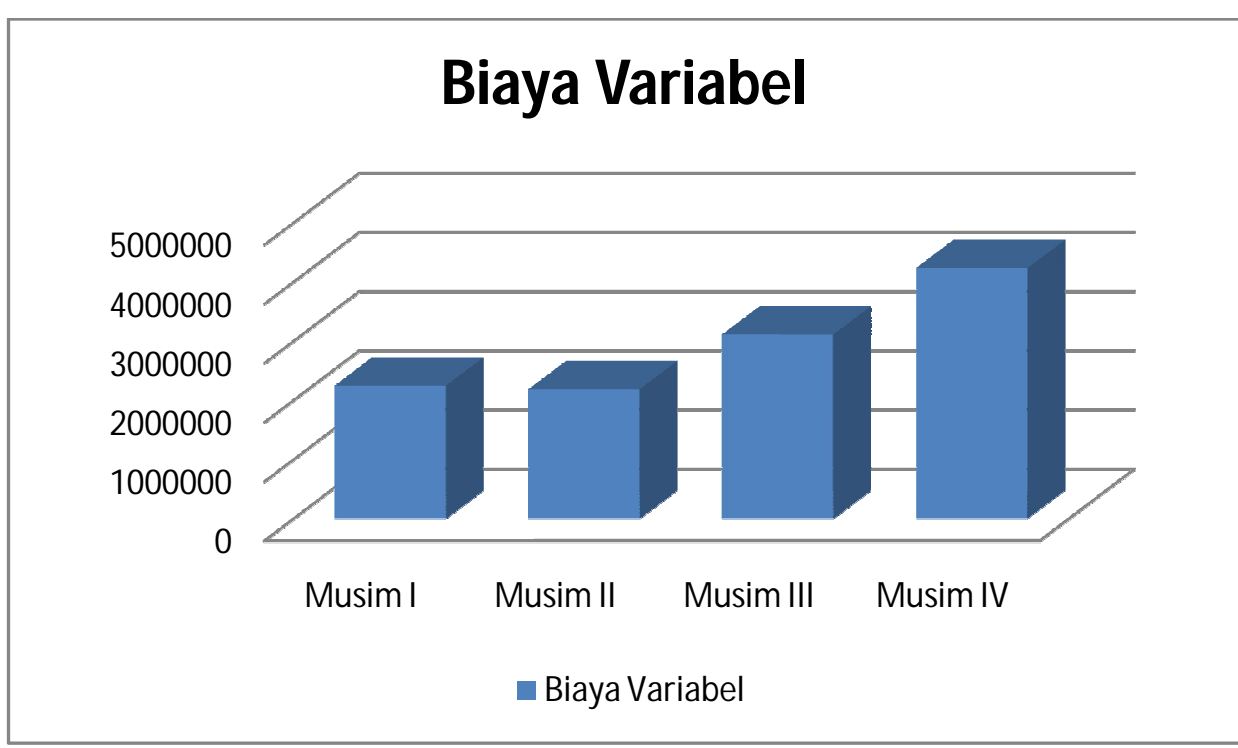

Variasi biaya variabel

(April-Juni) ada beberapa

disebabkan karena

besarnya biaya yang

nelayan yang tidak

dikeluarkan petani untuk

mengeluarkan biaya

tenaga kerja. Upah tenaga

tenaga kerja, karena pada

kerja pada usaha

musim tersebut banyak

penangkapan kepiting

rata-rata sebesar Rp.

$50.000,-/ \mathrm{HOK}$.

Penggunaan tenaga kerja

terbanyak yaitu pada

nelayan yang fokus pada

melaut (menangkap ikan)

sehingga jarang

musim IV, dimana

melakukan penangkapan

kepiting ataupun kalau

melakukan penangkapan

seluruh responden

mengeluarkan biaya

tenaga kerja pada usaha

penangkapan kepiting.

kepiting, nelayan hanya

mengandalkan tenaga

kerja pribadi atau

keluarga sehingga tidak

perlu membayar tenaga

Pada musim I (Januari-

upahan dari luar keluarga.

Maret) dan musim II 
2. Risiko Produksi

Analisis risiko produksi pada usaha penangkapan kepiting dilakukan dengan analisis koefisien variasi (CV) dengan menggunakan data produksi usahatani, seperti terlihat pada tabel 7, dengan nilai koefisien variasi sebesar 11,1 \%. Produksi kepiting dalam satu musim dapat mencapai rata-rata 5-10 $\mathrm{Kg} / \mathrm{hr}$ atau sekitar 100$150 \mathrm{Kg} / \mathrm{musim}$. Terdapat empat musim penangkapan kepiting yaitu : Musim I (Timur) terjadi pada bulan Januari-Maret, musim II (Utara) terjadi pada bulan April-Juni, musim III (Barat) terjadi pada bulan Juli-September dan musim IV (Selatan) terjadi pada bulan

Oktober-Desember.

Risiko produksi pada usaha penangkapan kepiting disebabkan oleh berfluktuasinya hasil tangkapan, dimana hasil penangkapan kepiting terbanyak terjadi pada musim IV (Selatan) yaitu pada kondisi nelayan tidak melaut (menangkap ikan) karena cuaca buruk sehingga nelayan beralih melakukan penangkapan kepiting. Gambaran ratarata hasil tangkapan kepiting berdasarkan musim tangkapan di Desa Mendalok Kecamatan Sungai Kunyit dapat dilihat pada gambar berikut.

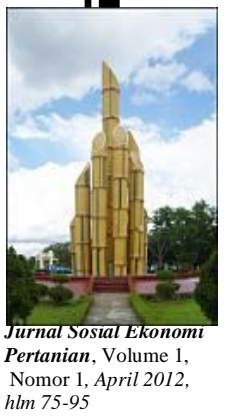




\section{Hasil Tangkapan Kepiting (kg)}

- Hasil Tangkapan Kepiting (kg)

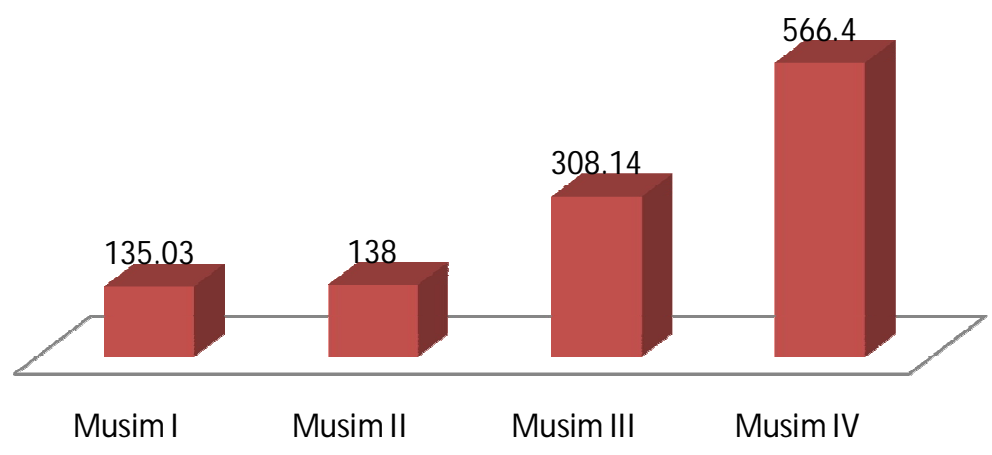

Gambar 1. Grafik Hasil Tangkapan Kepiting Berdasarkan Musim Tangkapan Di Desa Mendalok Kecamatan Sungai Kunyit

Pada saat penangkapan kepiting, nelayan melakukan penyortiran terhadap hasil tangkapan berdasarkan berat bersih per satu ekor kepiting. Kriteria hasil tangkapan yaitu memiliki berat 100 250 gr/ekor dengan panjang karapas 9-20 cm, dan jika yang ikut terperangkap adalah anakanak kepiting (memiliki berat $<100$ gr/ekor), maka akan dikembalikan lagi ke laut karena kepiting yang memiliki berat kurang dari berat standar juga tidak akan dibeli oleh pedagang pengumpul. Selain itu, nelayan juga mempertimbangkan kuantitas populasi kepiting, karena sampai saat ini nelayan sangat bergantung kepada hasil alam dan belum adanya usaha untuk melakukan budidaya kepiting.

Hasil tangkapan kepiting dibawa dan dikumpulkan di tempat pelelangan ikan (TPI) yang ada di Desa Mendalok, untuk 
dilakukan proses penyortiran kepiting yaitu jika kepiting dalam kondisi cacat misalnya capit patah maka kepiting ini tidak akan laku terjual dan selanjutnya hanya akan digunakan untuk konsumsi pribadi dan keluarga nelayan.

Variasi hasil produksi (tangkapan kepiting) juga disebabkan karena kondisi cuaca yang tidak menentu serta keterbatasan alat tangkap dan modal yang dimiliki oleh nelayan. Usaha penangkapan kepiting masih sangat bergantung kepada alam, karena sampai saat ini belum ada usaha yang mengarah kepada usaha budidaya kepiting, sehingga sangat dikhawatirkan akan terjadi penangkapan kepiting bakau yang tidak terkendali dan pada akhirnya menyebabkan kerusakan keseimbangan populasi kepiting di muara sungai.

Hasil tangkapan yang diperoleh oleh nelayan juga sangat tergantung pada jarak tempuh nelayan saat melaut, sehingga berpengaruh pula terhadap hasil tangkapan kepiting. Proses penangkapan kepiting yang dilakukan nelayan adalah dengan memasang umpan pada alat tangkap yang digunakan (bubu, pancingan, jaring, dan perangkap). Alat tangkap ini kemudian dipasang pada beberapa titik yang merupakan habitat kepiting misalnya pada sela-sela hutan bakau, tepi pantai, daratan berlumpur, dan laut. Biasanya terdapat beberapa kepiting yang terperangkap jaring di laut dalam kondisi bertelur karena kepiting ini akan melakukan pemijahan di laut. Kondisi suhu dan salinitas air laut cocok untuk melakukan

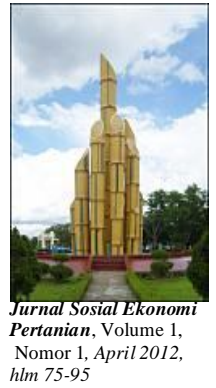




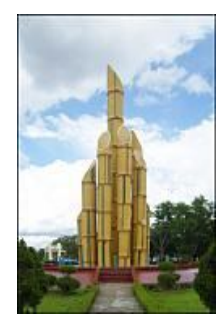

Maswadi, Dampak Penerapan Pungutan Ekspor Crude Palm Oil...

\section{Risiko Keuntungan}

Analisis risiko keuntungan pada usaha penangkapan kepiting dilakukan dengan analisis koefisien variasi (CV) dengan menggunakan data keuntungan usahatani, seperti terlihat pada tabel 7. Risiko keuntungan yang dihadapi oleh nelayan sangat besar yaitu sebesar 73\%, hal ini dikarenakan bervariasinya keuntungan yang diperoleh nelayan karena tergantung dari besar kecilnya biaya yang telah dikeluarkan oleh nelayan dalam melakukan penangkapan kepiting serta hasil tangkapan yang diperoleh. Nelayan akan mengalami kerugian besar apabila

sudah mengeluarkan biaya yang besar untuk tenaga kerja, tapi tidak mendapatkan hasil yang besar dan dengan kualitas yang baik. Keuntungan yang diperoleh nelayan juga sangat terkait erat dengan harga jual kepiting. Besar kecilnya harga jual kepiting tergantung kepada siapa nelayan menjual hasil tangkapannya, yaitu kepada pedagang besar, pedagang pengumpul atau pedagang pengecer. Jika nelayan menjual langsung kepada pedagang pengecer, maka nelayan akan mendapatkan harga jual kepiting Rp. 25.000,$/ \mathrm{kg}$, tetapi pengecer hanya mau membeli hasil tangkapan yang berukuran besar ( > 200 gr/ekor), dan biasanya membeli dalam jumlah yang terbatas atau sedikit.

Jika nelayan menjual ke pedagang besar, maka nelayan mendapatkan 
harga sebesar Rp. 20.000,-

$/ \mathrm{kg}$, tetapi pedagang besar hanya mau membeli dalam jumlah yang besar yaitu hasil tangkapan > 10-15 $\mathrm{kg} / \mathrm{hr}$ dan tidak mau membeli jika hasil tangkapan kurang dari standar. Hanya sedikit nelayan yang menjual hasil tangkapan ke pedagang besar, karena nelayan tidak bisa memastikan hasil tangkapan nelayan terutama jika pada bukan musim IV (musim dengan hasil tangkapan kepiting terbesar).

Jika nelayan menjual ke pedagang pengumpul, maka nelayan mendapatkan harga sebesar Rp. 15.000,-/kg. Harga yang diberikan oleh pedagang pengumpul merupakan harga terendah, akan tetapi banyak nelayan yang menjual hasil tangkapannya kepada pedagang pengumpul, dikarenakan tidak ada batasan pembelian ataupun ukuran standar kepiting yang bisa dijual oleh nelayan, karena masingmasing ukuran telah memiliki harga tersendiri. Bagi nelayan, harga jual dan keuntungan yang kecil tidak menjadi masalah asalkan biaya produksi penangkapan kepiting bisa tertutupi dan nelayan dapat menjual hasil tangkapannya setiap saat.

Proses pemasaran kepiting harus tepat waktu karena setelah ditangkap, daya tahan kepiting hanya sampai 3 hari. Beberapa nelayan yang hasil tangkapannya sedikit, biasanya akan menyimpan kepiting untuk sementara waktu dan kemudian menjualnya dengan gabungan pada hasil tangkapan berikutnya. Jika prosedur penyimpanan tidak sesuai maka akan terjadi risiko penurunan kualitas baik rasa maupun bobot kepiting. Sampai

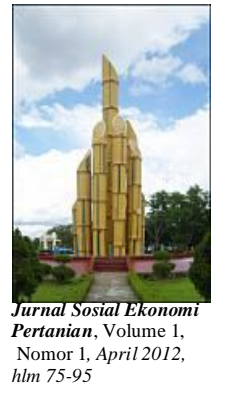




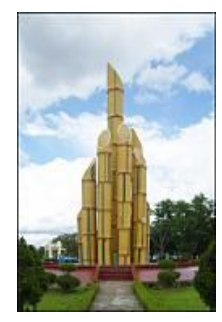

Maswadi, Dampak

Penerapan Pungutan

Ekspor Crude Palm Oil... saat

ini

teknis

penyimpanan

yang

dilakukan nelayan masih

sangat sederhana sehingga

bayak hasil tangkapan

yang tidak habis di jual

karena cacat, mengalami

kematian

ataupun

pembusukan. Jika hal ini

terus terjadi maka nelayan

akan mengalami kerugian,

karena kepiting yang

sudah mati atau cacat

produksi tidak memiliki

nilai jual.

\section{KESIMPULAN DAN}

SARAN

\section{Kesimpulan}

1. Usaha

penangkapan

kepiting di Desa Mendalok

Kecamatan Sungai Kunyit

Kabupaten Pontianak

mengalami keuntungan

dengan

rata-rata

keuntungan yang diperoleh

nelayan yaitu sebesar Rp.

9.531.357,-/tahun.

2. Risiko biaya pada usaha penangkapan kepiting bakau disebabkan oleh adanya variasi pada biaya tetap dan variabel. Risiko

produksi disebabkan oleh

berfluktuasinya hasil

tangkapan, keterbatasan

sarana dan prasarana serta

terbatasnya modal. Risiko

keuntungan disebabkan

oleh bervariasinya hasil

tangkapan kepiting serta

adanya perbedaan harga di

tingkat pedagang

(pedagang pengecer,

pedagang pengumpul dan

pedagang besar.

\section{Saran}

1. Usaha penangkapan kepiting di Desa Mendalok Kecamatan Sungai Kunyit merupakan salah satu alternatif untuk meningkatkan pendapatan nelayan. Tetapi dalam pelaksanaannya, nelayan dihadapkan pada risiko yaitu risiko biaya, risiko produksi dan risiko keuntungan. Salah satu cara untuk meminimalkan risiko dan meningkatkan pendapatan nelayan yaitu dengan melakukan usaha 
budidaya

kepiting,

DAFTAR PUSTAKA

sehingga nelayan tidak

tergantung hanya kepada

Afrianto, Eddy \& Evi liviawati

alam dan hasil produksi

, 1992 ,Pemeliharaan

kepiting bisa lebih stabil

(tidak terlalu bervariasi).

2. Nelayan masih dihadapkan

pada kendala terbatasnya

sarana prasarana dan modal

yang dibutuhkan dalam

usaha penangkapan

kepiting, sehingga

diperlukan dukungan dari

pemerintah dan instansi

terkait terutama dalam

bantuan penyediaan modal

dan sarana prasarana,

misalnya alat-alat

tangkapan, perahu dan

mesin tempel.

3. Perlunya bantuan

penyuluhan dari pihak

pemerintah atau instansi

terkait dalam hal

pengenalan usaha budidaya

kepiting, prosedur

penyimpanan, serta

standarisasi dan grading

hasil tangkapan kepiting.

Kepiting , kanisius ,

yogyakarta

Ayodyhoa , 1981, Dasar-dasar

penangkapan ikan,

Fakultas perikanan

universitas

Brawijaya,malang.

Azzaino, Zulkifli, 1991,

Pengantar Pemasaran

Pertanian, Departemen

ilmu sosial ekonomi

pertanian IPB, Bogor.

Badan Pusat Statistik

Kalimantan Barat,

2001,DataＳtatistik

Kecamatan Sungai

Kunyit dalam

angka,Bps Kabupaten

pontianak.

Maulidi, Sitorus dan Mahdi.

1992. Analisis

Pemasaran Jahe

Gajah di Jertra

Produksi Sumatera

Utara dalam Littro No.

2 Vol. VIII. UPB

Bogor.

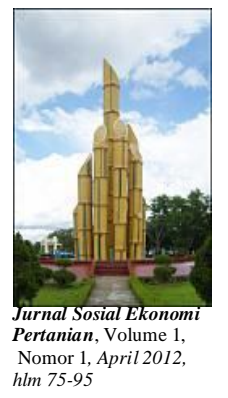




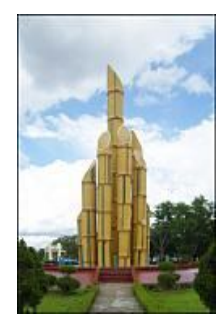

Maswadi, Dampak

Penerapan Pungutan

Ekspor Crude Palm Oil...

Nazir, M, 1988, Metode

Penelitian Sosek, Galia

Indonesia, Jakarta.

Soekartawi. 2003 . Prinsip-

Prinsip

Ekonomi

Pertanian. Rajawali

Press. Jakarta.

Stanton, J.Wiliam. 1984.

Prinsip Pemasaran,

Erlangga.Jakarta.

Swastha, Basu. 1990. Asasasas Marketing.

Liberty.Yogyakarta.

Saladin, Djaslim. 2003. Intisari

Pemasaran dan unsurunsur Pemasaran.CV.

Linda karya. Bandung.

Stanton, J. Wiliam, 1993.

Prinsip-Prinsip

Pemasaran. Jilid I. PT.

Erlangga. Jakarta.

Lipsey,Richard. G, et, al. 1987.

Pengantar Mikro

Ekonomi. Alih Bahasa

Jakawarsana dan

Kitbrandoko. Penerbit

Erlangga Jakarta.
Kotler, 1997. Manajemen

Pemasaran. Jilid I.

Prenhalindo. Jakarta

Kanna,Iskandar 2002,

Budidaya Kepiting

Bakau, Kanisius.

Yogyakarta.

Swasta, $\quad$ Basu. 1990.

Manajemen

Pemasaran

Moderen.Penerbit

Liberti Jakarta.

Saefudin, A. M. 1982.

Pendeakatan sistem

Pemasaran Komoditi.

IPB Bogor

Suparmoko \& tagiran, 1991.

Metode Penelitian

Praktis (Untuk Ilmu-

ilmu Sosial dan

Ekonomi), BPFE-

UGM, Yogyakarta.

Limbong, Wilson. $\mathrm{H}$ dan

Panggabean Sitorus.

1988. Pengantar

Tataniaga Pertanian

Soekartawi. 2003. Agribisnis

Teori dan Aplikasinya

PT Raja Grafindo

Persada, Jakarta oleh 
Downey, W. D dan Steven

Erickson, Manajemen

Agribisnis, Alih Bahasa

oleh Rockdial Ganda S

dan Alfonso S, 1992,

Penerbit Erlangga

Hanafiah \& Saefudin, A. M.

1986, Pendekatan

Sistem Pemasaran

Komoditi, Bogor :

Institut Pertanian

Bogor.

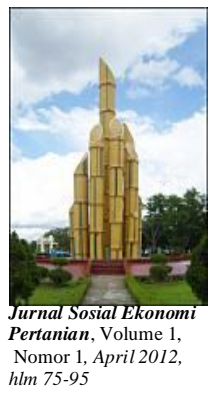

